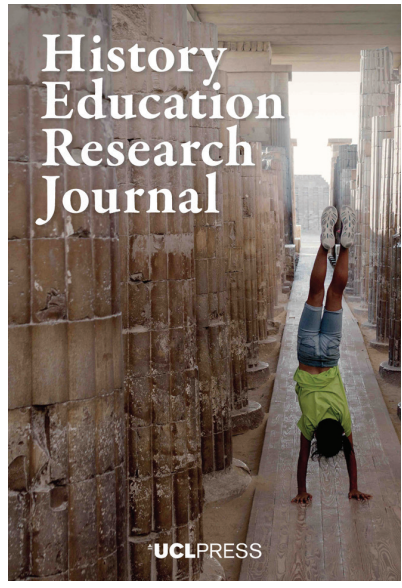

${ }^{\Perp}$ UCLPRESS

HISTORY EDUCATION RESEARCH JOURNAL

ISSN 2631-9713 (Online)

Journal homepage:

https://www.uclpress.co.uk/pages/history-educationresearch-journal

\title{
Of dragons and dinosaurs: How children's toys and games create ideas of the past, of history and of fiction
}

\section{Christoph Kühberger iD}

\section{How to cite this article}

Kühberger, C. (2021) 'Of dragons and dinosaurs: How children's toys and games create ideas of the past, of history and of fiction'. History Education Research Journal, 18 (2), 183-98. https://doi.org/10.14324/HERJ.18.2.04

Submission date: 16 October 2020

Acceptance date: 15 June 2021

Publication date: 19 October 2021

\section{Peer review}

This article has been peer-reviewed through the journal's standard double-blind peer review, where both the reviewers and authors are anonymised during review.

\section{Copyright}

(C) 2021 Kühberger. This is an open-access article distributed under the terms of the Creative Commons Attribution Licence (CC BY) 4.0 https://creativecommons.org/licenses/by/4.0/, which permits unrestricted use, distribution and reproduction in any medium, provided the original author and source are credited.

\section{Open access}

The History Education Research Journal is a peer-reviewed open-access journal. 


\title{
Of dragons and dinosaurs: How children's toys and games create ideas of the past, of history and of fiction
}

\author{
Christoph Kühberger* - University of Salzburg, Austria
}

\begin{abstract}
This article outlines a trend in popular historical culture which has seen the increasing replacement of a concept of history that rests on some form of evidence base by visions of fictional pasts, or - to put it more precisely - by an ambiguous blend of the past and fictional pasts. Drawing on ethnographic research focused on the contents of Austrian children's rooms, this paper explores traceable manifestations of history and historical fiction, particularly toy dragons and dinosaurs, in their properties as objects and as focuses of their owners' interpretations as ascertained in interviews. The research finds little clear demarcation in the minds of the children interviewed (all between 8 and 12 years old) between imaginings and cognitive attempts to reconstruct the past. The article examines the influence of these factual-fictional representations on historical thinking from a history education perspective.
\end{abstract}

Keywords: toys, children's rooms, historical thinking, historical culture, fiction

\section{Introduction}

In recent years, we have been able to observe a trend in historical culture which has seen the increasing replacement of a factually based interest in the past by what we might term a 'fictionalised' approach, or - to put it more precisely - a blurring of the boundaries between the past and a fictional, fantastical version thereof (De Groot, 2016). This phenomenon has reached the themes of children's play, with plastic knights meeting plastic flying dwarves in children's bedrooms and playrooms, and sea monsters materialising from the deep to devour pirates. I wish to commence my discussion of this phenomenon by stating that it is not my intent to lament it; it is a facet of culture in all its fullness. What this article will seek to ascertain in this context is threefold. First, it will attempt to identify, on the basis of ethnographic evidence from children's home play spaces, what past or fictional worlds emerge through commercial play products, and pinpoint the shift that has occurred from broadly 'objective' modes of representing the past to an encompassing fictionalisation of the historicised setting offered. Second, the article introduces a history education perspective, exploring children's thinking about history and the historical culture that they consume outside the school setting. Finally, it considers how children play in and with these worlds.

The discipline of history education in German-speaking countries has a broad-based tradition of engagement with publicly available manifestations of historical culture, such as feature films about the past, history magazines, television documentaries, computer games and so on (see Oswald and Pandel, 2021; Hinz and 
Körber, 2020). In contrast, the field has thus far shown little or no interest in children's consumption of history outside formal settings (Kühberger, 2020). There has been an assumption that products representing an imaginative interaction with the past, which we see around us in shops, on television and at the cinema, would automatically appear among all children's toy collections. It is an assumption that my ethnographic research around and in children's play spaces, in the course of which the 'locals' guided me and my fellow researchers through their 'culture' and showed us their world, has not borne out. The contents of bedrooms and playrooms belonging to 8-12-year-old children in Austria, and doubtless in other countries, are highly diverse. Some children live amid a sea of toys, books, audiobooks, games, stuffed animals and other objects that have some connection to 'the past'; others have rooms devoid of products with historical references, preferring to follow their interests in science, mathematics, music or other fields. It is, however, certain that engagement with the historical in children's personal play worlds is not a marginal phenomenon, and that 'the past' takes a variety of forms for children in this context. The objects around which this article revolves are located precisely in this area of interface and overlap between history and fantasy.

As part of a substantial project exploring historical culture in children's bedrooms and home-based play spaces, the study described in this article represents an attempt to conceptualise and examine informal learning in personal settings as a significant component and indeed a prerequisite of formal history education. Children's encounters with a diverse range of representations of the past as they play in their rooms give rise both to ideas about the thematic focuses of the toys to which they have access, and to concepts about the theory of history, which they then bring to school with them. To date, the academic discipline of history education has tended to neglect, or indeed ignore outright, the significance of these factors and their creation of a basis for formal historical learning. Nevertheless, we need to take this into account if we are to understand and work with the enduring effects of this childhood engagement with interpretations of the past in children's home-based worlds. In this spirit, and with a specific focus on dinosaurs and dragons, this article explores and discusses: how we can approach, understand and interpret historical themes in children's play; the forms taken by the dragons and dinosaurs that children encounter in their play worlds; children's conceptual ideas about these beings, drawn from popular historical culture; the significance of their play with them; and the implications for history education.

\section{Research methodology}

Any attempt to place on an evidence base the occurrence of products of historical culture in the private spaces of children's bedrooms and playrooms, or the types of interactions with history which take place there, will inevitably lead the researcher into what is currently a terra incognita for history education. The insights provided here are based on an excursion into that terra incognita - the field studies that my students and I conducted in Austrian households in 2017 and 2018. The conduct of ethnographic research with children requires special ethical standards (Christians, 2000; Alderson and Morrow, 2011); the University of Salzburg's Ethics Committee accordingly reviewed the research design, instruments, and data handling for the study reported in this article and came to a positive judgement. As it is not possible to undertake long-term participatory observations in children's rooms, we opted for short visits with a parent or parents present, and the door of the room open at all times. Case studies of 19 children's bedrooms form the basis of this article. The highly personal and sensitive nature of these spaces, which are usually accessible only to the children themselves, 
their friends and members of their families, meant that, when planning the research, I did not necessarily expect that we would be able to: (1) take digital photographs; (2) audio-record the children guiding the researcher through the room; or (3) conduct expert interviews with the children in their rooms. We were, in fact, privileged to have the opportunity to do all three. In order to gain this level of trusted access to these spaces, the researchers worked within their own broad networks of contacts to recruit participants to the study (Kühberger, 2019).

It is, of course, important to contextualise the insights gained thus far with regard to our sample. The broader research, which is ongoing, has attempted to include the widest possible range of children, with a variety of social and cultural backgrounds, in order to be able to draw as diverse a picture as possible. The rooms we visited for this article belonged to children aged 8 to 12 from the Austrian middle class, living in various urban and rural areas in Western Austria, with parents working, for example, as doctors, teachers, sales assistants and farmers. In obtaining the profound impressions we gained of these highly personal spaces, and the toys and games within them, we used mainly qualitative approaches, with some quantitative data collected in the children's rooms. The ethnographic approach of the work is based, in particular, on the research methods used by Siân Lincoln (2012: 51) in the study Youth Culture and Private Space, for which she conducted in-depth ethnographic interviews and took photographs in teenagers' rooms with the objective of exploring their 'identity spaces'. The exhibition on Teenage Bedrooms (2016/17) at the Geffrye Museum (now the Museum of the Home) in London likewise served as inspiration for our research.

A primary driver of the many and varied facets of the historical that we encounter in children's rooms is, of course, the toy industry, which in turn generally does no more than pick up on cultural trends related to history and recondition them for the youngest members of society. We note the occurrence in this context of figures such as fairies, ghosts, magicians, dwarves and other fictional beings, which have always been present in children's play worlds, but which now find themselves juxtaposed or fused with characters whose conceptions draw - ostensibly or actually - on history. In a media landscape with broad and numerous audiences, popular film series such as The Lord of the Rings (2001-3) and Pirates of the Caribbean (2003 onwards), alongside fantasy television series, notably including Game of Thrones (2011-19), and books and their film adaptations, such as the Harry Potter series (books, 1997-2007; films, 2001-11), encapsulate a liminal space between historical and only apparently historical settings, with characters often marked as fantastical, but simultaneously firmly rooted in spheres of presentation and depiction that resemble, reference or constitute historical contexts (Bernhardt, 2016; Curthoys, 2014; Eissle, 2009). In seeking entry into this arena of intersection and blurred boundaries between history and fiction, this article, discussing the exemplary case of play-based interaction with dragons and dinosaurs, seeks to pay appropriate regard to children's immediate life-worlds as a basis and backdrop for formal historical learning which history education cannot afford to ignore.

\section{Dragons and dinosaurs in children's play spaces}

This article will focus on dragons and dinosaurs - as toys and as imaginative phenomena - in children's bedrooms. I have yet to explain why I am discussing the fictional dragons - alongside dinosaurs, whose existence is palaeontologically proven. The reason lies in cultural history. For a long time, notions of these two sets of beings overlapped extensively. Until the nineteenth century, natural history was in many respects an uncharted terrain, and even scholars relied upon biblical and other ancient 
texts in interpreting prehistoric finds, which rendered them unable to put the existing narrative pool of established legends and popular traditions outside their sphere of reference. Abstruse, ominous and obscure explanations for such finds were inevitable, particularly in instances where the location of ancient remnants, such as caves, or their inexplicable size, cast them in an uncanny light and activated fearful phantasms in those who discovered or learnt of them (Groiß, 2002: 55-6). Works of natural history and literature from antiquity, the Middle Ages and the modern era alike were particularly wont to describe dragons as real beings (Rebschloe, 2014; Schneidewind, 2012); as such, their existence appeared proven. Although I will refrain from going into further detail about the figures' literary genesis, or about the symbolic references and new creations that emerged in this context, I will note that the evidence for a 'lumping together' of dragons and dinosaurs, over a long period of time, is unambiguous. It therefore seems, certainly from an academic perspective, almost strange that a twenty-first-century palaeontologist should name a newly discovered dinosaur species 'Dracorex hogwartsia' (Dragon King of Hogwarts), referring to the Harry Potter books, because of its distinctive skull shape, reprising this pre-modern amalgamation of the literary/fantastical and the scientific (Sullivan, 2006). Alongside this association with actuality, cultural associations with dragons, particularly in Christian religious traditions and in the literary/symbolic realm, were often mythical or miraculous, or instead, on occasion, distinctly negative.

Our investigations gave rise to quantitative data acquired in the course of the researchers' visits to children's rooms and the conversations that they had with the children. We systematically recorded the photographs that we took of the rooms, along with the toys and games that the children showed us, supplementing this information with insights from the interviews, which were coded using MAXODA. This procedure enabled us to quantify the dinosaurs and dragons on display in children's rooms and populating their play worlds, insofar as the children mentioned them in the course of the interviews. Both dinosaurs and dragons are in evidence in the corpus presented here $(n=46)$, in the form of toy figures, posters, books, stuffed animals, board games and so on. Dragons are clearly dominant, accounting for 75 per cent of the corpus, compared to 25 per cent for dinosaurs. Looking more closely at the findings, we note that dinosaurs appear subject to a gender-specific ascription (Figure 1). Boys seem to receive more ideas and inspiration about this area of the past - or pick them up more frequently - than girls, whereas dragons 'inhabit' the rooms of children of both sexes. This accords with further findings in relation to this age group, such as the account by Eva Änggård (2005) of a primary-school free-writing project in which only boys produced heroic tales incorporating both dinosaurs and knights.

- Dragons Dinosaurs

26

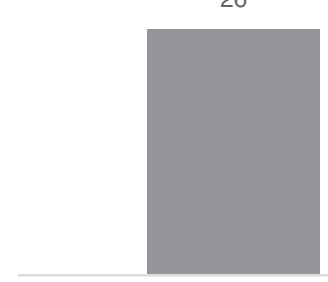

Boys
24

15

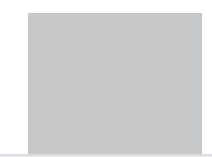

2

Girls

Figure 1: Gender-specific findings $(n=46)$ 
Breaking down the data to the level of individual children's rooms (Figure 2) puts this finding into perspective; we see that five rooms - three belonging to boys and two to girls - feature neither of these categories of beings.

These statistics, albeit limited in scope and drawing on qualitative ethnographic research, are clearly indicative of the evident popularity of dinosaurs, and especially of dragons, in children's play worlds. The frequency of dragons' occurrence is doubtless due in part to the multiple representations of these creatures available today. A further factor, however, and one of particular significance for children's learning and socialisation processes, is the correlation between specific stages of child development towards rationality and traditional cultural representations of these mythical beings; the conception of dragons at the time of its pre-modern emergence, like the thinking of children, appears to reject or elude an unambiguous distinction between imagination and the perception of 'reality' (Petzold, 2012: 175). Selma Fraiburg (1998) calls this developmental stage the 'magical phase'. History education points to fairy tales as a frame by which children can discover and come to understand the world, and which they activate in their early historical thinking. Fairy tales make space and provide interpretations for the magical, the enigmatic and the mysterious. Waltraud Küppers's (1961: 41) study - still of relevance to discourse in the discipline today, in the absence of more recent empirical data from German-speaking countries - identifies a 'fairytale-like-mythical conception' of the past among children at the end of their primary schooling (see also Roth, 1955: 68-9). Difficulty in distinguishing between fantasy and reality is evidently not confined to pre-schoolers. Persistent ideas in this direction remain in the minds of children far beyond that early stage: 'Adults should be aware that children might assume that the events in stories could happen in real life, and when appropriate, explicitly describe the story as make-believe' (Samuels and Taylor, 1994: 426). Although it is obvious that the opposite of 'play' is 'reality' (Lehmhaus and Reiffen-Züger, 2018: 29), images of, and encounters with, representations of the fictional and/or historical past often continue to loom large in children's minds as they grow and leave 'play' behind; teenagers and adults who seek to lose themselves in such worlds may have retained a degree of child-like thinking or may desire an escape from the purely rational.

Returning to the present-day children's bedrooms that our research explored, we observe that a primary locus of the depiction or representation of dragons appears to be books, including Harry Potter, The Legend of Zelda and Austrian Legends, and books depicting the popular children's character 'Der kleine Drache Kokosnuss', literally

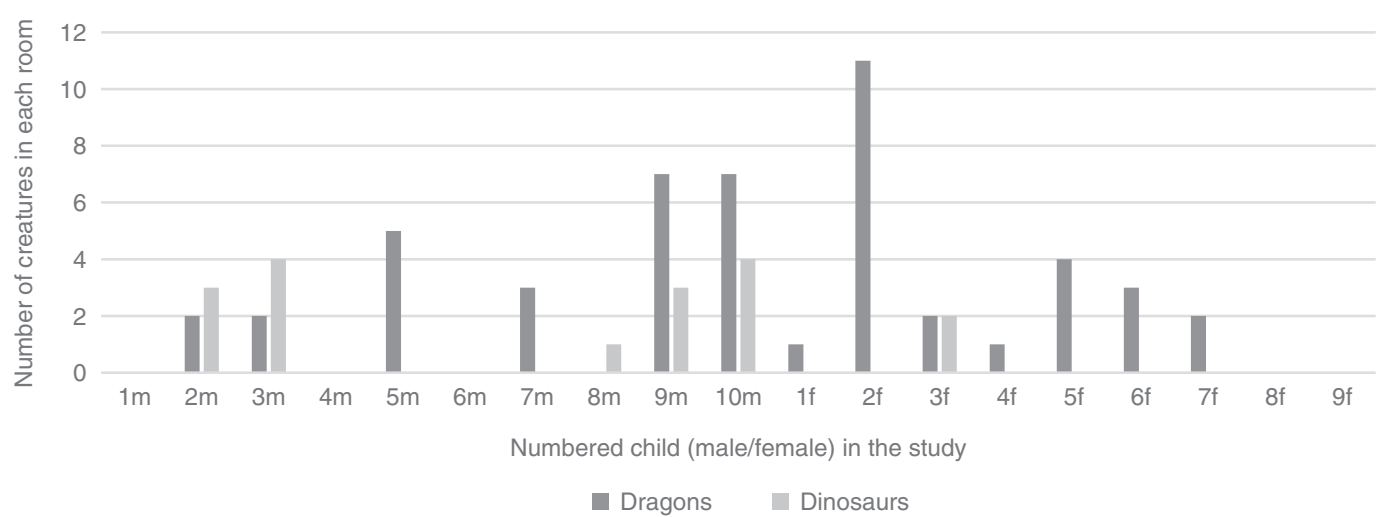

Figure 2: Dragons and dinosaurs in 19 Austrian children's bedrooms 
'Coconut the Little Dragon' (Figure 3). Dragons' entry into children's play spaces, then, continues to take place via their narrative depiction in the fictional context, usually combined with pictorial representations in children's and young people's books. Frequent associations are likely to be the motto of Hogwarts in the Harry Potter books, 'draco dormiens nunquam titillandus' ('Never tickle a sleeping dragon'), or local legend, such as the Austrian Lindwurm myth from Klagenfurt.

I do not intend to reprise the voluminous quantity of existing research on literary phenomena of this type, but rather to focus on other aspects of this topic; that said, it is worth being aware that literary motifs are often inescapable in this context. Although these phenomena are increasingly diffusing through and permeating popular culture with ever more indistinct boundaries with neighbouring tropes and images, and without consumers of these cultural products being aware of their actual context - traditional narratives are often at work in the background. Ultimately, however, studies on the literary heritage of narratives, and on the depiction of dragons in modern narratives, have shown that dragons, as modern and postmodern figurations present them, have become removed from the medieval dragon, or, put differently, have evolved from it, and are often only distant relatives of their literary ancestors. Their domestication and trivialisation have given them an entirely new image - the cartoon figure of Grisù is a good example (see Rebschloe, 2014: 378; Bonacker, 2012). However, as Timo Rebschloe (2014: 379) emphasises:

If we survey the development of the dragon as a figure, the indeterminacy [in appearance and nature] of its modern incarnation does appear to us as a legacy of medieval times. In contrast to the original monsters [that appeared in older narratives] ... dragons lost their unambiguous association with negative attributes ... as early as the Middle Ages. Further, they were already transitioning [at this time] into a liminal space from which they would depart, in the modern era, in the direction of straightforward, conscious and deliberately designated fictionality.

The bedrooms of our interviewees bear distinct traces of these transitions and evolutions. If we set aside the linguistic and literary iterations of the concept, and the notably subtle and muted references to this tradition around the depiction of dragons, we can conceive of the dragons we meet in children's play accoutrements

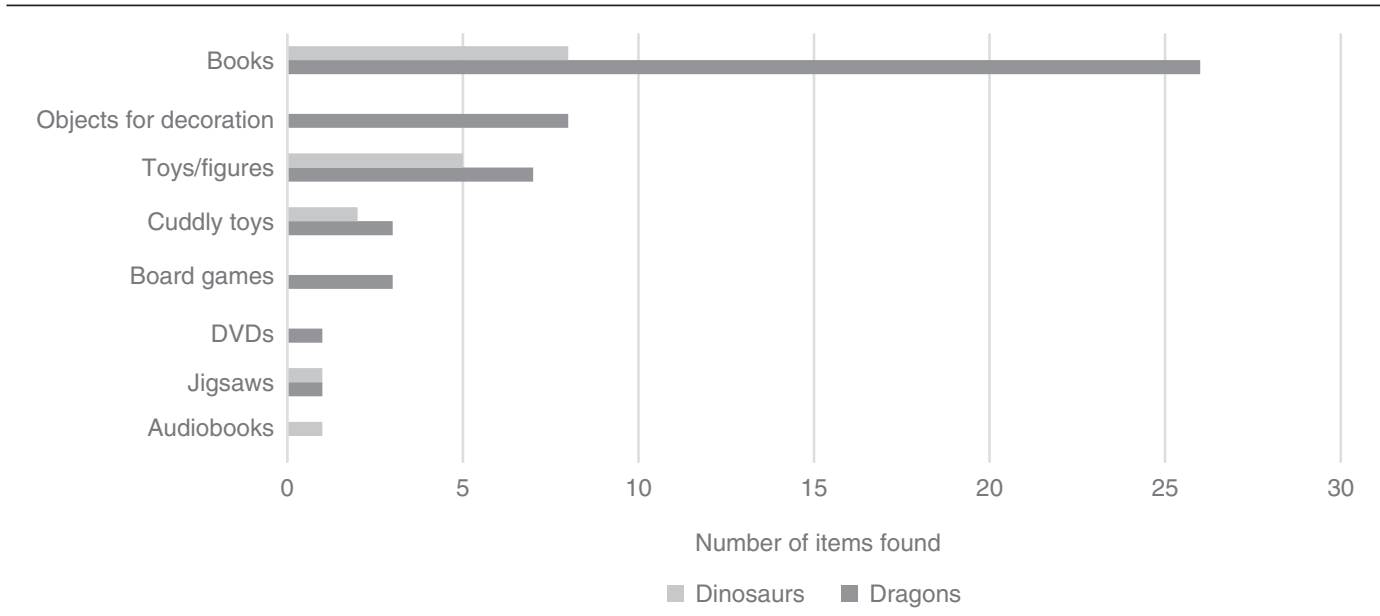

Figure 3: Types of dragons and dinosaurs found in bedrooms belonging to 19 Austrian children 
as domesticated beasts. Some of them live in their owners' rooms without further narrative context; these include stuffed animals and decorative figures. For those located within encompassing, themed play worlds, however, the case is different. The room of a 12-year-old boy, for instance, featured two knights displayed on a shelf, each mounted on a dragon. In a girl's room, a Playmobil set themed 'Princess's Birthday Party' (Playmobil, No. 6854) showed the distinctly modern-looking princess, not quite at one with the baroque-style setting, receiving a toy dragon as a gift. A room belonging to a 10-year-old boy revealed a much more conventional view. The researcher found a red and black Playmobil dragon with huge wings enthroned alongside a globe in pride of place, conferring upon the dragon a special status as an evident survivor of a cull of Playmobil worlds from its owner's play universe; indeed, in the interview, the boy remembered that the dragon had belonged to his Playmobil castle, which he no longer kept in his room. The dragon stood separately from another extensive collection of over fifty plastic figures, in a relatively free-standing and elevated position. The manufacturer, which calls it a 'Giant Dragon with LED Fire' (Playmobil, No. 4838), notes on its website that 'When the Giant Dragon with LED Fire appears, all [its] enemies turn pale with fear: it is not only the most powerful dragon that ever walked the earth, but its flame-red fire breath also makes it invincible!' What this blurb fails to mention is that the dragon also has a rider, and must therefore be considered domesticated. The figure of the rider bears armour and weapons reminiscent of a knight, but its lance is worked at the lower end as a kind of magic wand with a spherical, transparent plastic stone.

Our discussion of the phenomenon would be incomplete without reference to the various dragon figures associated with the computer-animated television series DreamWorks Dragons (2012-18), which typify the layers of cultural reference in evidence in the dragon phenomenon. The children's bedrooms in which we did our research contained play figures, bedlinen, posters and board games produced by a range of manufacturers, all referencing the series' repertoire of characters. One boy and two girls in our study had merchandise in their rooms, including film posters, decorative articles and, in one instance, a toy figure of 'Toothless', who is ridden in the series by his friend 'Hiccup' the Viking (Playmobil, No. 9246).

Consideration of the context in which these dragons are embedded, and of their target group, might lead us to wonder whether we can indeed assent to the claim of literary scholars that, in our times, the dragon is a being of clearly signified fictionality the assertion appears to have limits within children's bedrooms, and particularly in their minds. I draw here on a further example, the illustration of a dragon on the box of the Ravensburger board game Labyrinth. In concert with the other instances of dragons encountered and discussed above, we see a being not located in a world beyond, but directly in the midst of people, among knights and Vikings, or in a labyrinth to be explored.

\section{Conceptual ideas about dragons}

In some interviews, the overlapping of these play themes, which simultaneously reference the past (knights, Vikings) and feed the fictional/fantastical imagination, led interviewers into fascinating conversations with children as they disclosed their views about their toys. An 11-year-old girl (Case 4w) who had previously mixed fictional or fantastical notions (fairies) and the factual past did so again in reference to dragons:

Girl: Hmm, I've also got a [game] with castles, it's my favourite game actually, Labyrinth. It works like this ... 
Interviewer: Mhm, can you get that down [from the cabinet] again, please? Girl: Mhm. It's about ... you can see it [on the box] anyway, about dragons and princesses and goblins and ghosts and so on and so forth, and witches and wizards.

Interviewer: Like the way things used to be?

Girl: Yes, exactly ... [Explains the game]

Interviewer: ... Is it [the game] about the past? Is that a time that used to be, once was? Like with an old book and treasure and a dragon and so on? Girl: Well, yes, I suppose, because all that doesn't actually exist any more. Interviewer: OK, and if you play a game like that now, are you interested in the way things used to be, and do you also look at things like that on the internet or in other things, for example about dragons?

Girl: Umm, no, so on the internet I don't look at it, umm, so I look, I'm just interested in playing it and so on, and yes, I suppose it's also because that's something you don't see any more today, now, nowadays, except in an old museum where there are exhibits about past times and so on and so on. So I don't really look things like that up on the internet.

Interviewer: Do you think, for example, that a dragon really looked like it's been drawn here? Or how do you imagine it?

Girl: Hmm ... well, I don't think it looked the way it's drawn. I think maybe it was green [as in the picture on the box], but I can't really say exactly, I just guess as a feeling that I don't think it looks like here.

When a 9-year-old girl (Case $1 \mathrm{w}$ ) whose room contained a plastic dragon was asked to assign it to a particular play world, she placed it with the knights. She then confirmed that knights had really existed, but was unsure whether there had been knights with dragons ('I don't know'). It is likely that structures of thought and uncertainties of this type stem from the contexts supplied with the toys or other objects. The co-presence of knights, which children encounter on various cultural and historical levels as (real) people belonging to the past, seems to classify the dragons accompanying them likewise as beings from the past. Like literary narratives, the production of toys in the same material, using the same spectrum of colours, with the same sets of possible sizes and so on, appears to give rise to a 'narrative plausibility' (Rüsen, 2013), which tends to be closed and coherent in itself. It would doubtless be of value to attempt to identify additional factors which blur the lines between the past and fictional fantasy, leading to the creation of a representation that can pass itself off as history ('historical past'). As an example, applying a theoretical concept set out by Kicks and Martin (1997) to a Playmobil knights' castle with dragons, factors that support an apparently unbroken cohesion or contiguity between past realities and fiction may be as follows: (1) a historical theme (knights, castle); (2) the emergence of an emotional and psychological bond with the object via the user's interaction/play/identification with it; (3) play which is free of anachronisms of fact, interpretation, emotion or psychology; (4) the establishment of a coherent storyline that does not concern itself with issues of historical tradition or fidelity to historical sources; (5) the figures involved in the play can all be controlled and are subject to the individual or shared logic of the player or players; and (6) the topic of play relates to an unknown society (alterity).

It is not the various play themes in evidence in children's bedrooms that forge links among themselves; the rooms feature knights next to dinosaurs and pirates, alongside books about the Stone Age. But there are children who connect dragons with dinosaurs of their own accord; they create their own logic. It appears unsurprising that children set up their own explanatory models for the dragon-dinosaur connection. 
One of my students, Beatrice Wieser, in an auto-ethnographic piece written in 2017, describes her memories of her childhood around the turn of the millennium thus:

On receiving dinosaur figures as a gift from the boy next door, another passion was awakened in me: dinosaurs. I collected the figures and swapped them with others. My walls were covered with all the different species of extinct mammals [sic]. Be it Tyrannosaurus, Sauropoda, Compsognathus or Struthiosaurus - I had them all at home, in miniature format or as posters. I have just realised while writing this report that I can no longer think of many of the names - a pity, really. I also notice that, at the age of eight, I never wondered whether it was historically possible for a society of knights to keep dinosaurs outside their castle. I thought about it some more and [asked] my mother, [who] was able to tell me that she had once asked me if I thought that the real knights had had dinosaurs in their gardens. I justified my YES! by saying that my knights' castle also had a dragon, which I evidently put in the same category as dinosaurs. As the [dragon] was part of the knights' castle set, I must have assumed that dinosaurs and knights had been around at the same time.

Exposing children to a range of toys clearly provides optimum stimulation for their imaginations. At the same time, children try to comprehend regimes and systems. The analogy constructed in the example above between dinosaurs and dragons - the latter having been supplied with the knights' castle - means that the child created a little dinosaur garden in the castle grounds.

Returning to the children's bedrooms of today, as they appear in our study, I note a perception, held by two boys in the sample, of an evolution from dinosaurs to dragons. As a result of reading a children's book, an 8-year-old boy (Case 9m) clearly believed that knights and dragons belong together, pre-dated by dinosaurs; he explained: 'And when all [dinosaurs] died, then the dragons [came].' An 11-yearold boy (Case $3 \mathrm{~m}$ ) came to similar conclusions. During the interview in his room, he showed the interviewer a puzzle depicting various dinosaurs:

Interviewer: ... Do you like dinosaurs?

Boy: Yes, they're great. They're so dangerous and look so fierce. I have another [puzzle] of them. Mama probably put that in here, too. Ah! Here it is! [Shows a puzzle with two dragons on the cover (Ravensburger, No. 19638)]

Interviewer: Oh, and what can we see there?

Boy: Dinosaurs too, you can see that.

Interviewer: I see. And why do they look so different?

Boy: Yes, because these lived earlier [points to the puzzle with the dinosaurs (Ravensburger, No. 13695)]. They don't have those wild prongs on their heads yet and don't all have wings yet. And later on they looked like this [points to the puzzle with the dragon motif]. Well, they certainly weren't the same, but you can see that on the one [puzzle] you don't see anything except grass and stuff. That's why. Look, I've even got a few dinosaurs over there. See how fierce they look [points to dinosaur figures].

The reference to the two puzzles in particular gives us an insight into children's thinking in this regard. The puzzle boxes present the dinosaurs in what is intended to be a natural landscape, and the dragons in a foggy setting of ruins, suggestive of human life. Additionally, the level of detail evident on the dragon puzzle box seems to indicate 
a higher evolutionary stage than that attained by the dinosaurs. The sense of twilight and fog on the dragon box, probably intended to conjure a mythical atmosphere, eludes decoding, which is why the boy did not perceive it.

There were also children in the sample - one instance is a 12-year-old girl (Case 7w) who we interviewed - who do not think that dinosaurs actually existed. Of particular interest in this context are the views of a 10-year-old boy (Case $2 \mathrm{~m}$ ), who cited knowledge whose sources are to be found in his room:

There was no such thing as dragons. They're imaginary creatures. I've got an audio CD about someone called Charles Darwin ... he invented the dinosaurs, ... I mean, he discovered them ... when younger children are 4, 5 years old or smaller, they think that dragons also belonged to the Middle Ages. That's just meant for younger ones. And if they, like, have a castle, then a giant dragon comes along and they play 'Oh no, the giant dragon is attacking me! We're all going to die! We've got to barricade ourselves in the castle, then maybe we'll survive!'

These ethnographic observations enable us to propose an initial rough model of children's conceptual patterns of thought around these topics, which fall into three types: (1) dragons as real, extinct beings; (2) dragons as real beings in evolutionary proximity to dinosaurs; and (3) dragons as imaginary beings. It is unfortunate that we are unable at this stage to supplement these qualitative findings with quantitative data on primary-age children's capacity to differentiate fantasy from (past) reality, as previous studies have obtained for younger children (see Morison and Gardner, 1978).

We should not overlook the determining influence of the toy industry in this. A comparative analysis of Playmobil catalogues issued by the toy manufacturer geobra Brandstätter Stiftung \& Co.KG between 2000 and 2018 (Figure 4) is illustrative of the extent to which dragons and dinosaurs, like other phenomena, are subject to economic cycles. This analysis counted the number of instances, in the principal catalogues issued by the company for each year, of individual illustrations depicting dragons and dinosaurs within set sceneries and products containing one or more dragons or dinosaurs.
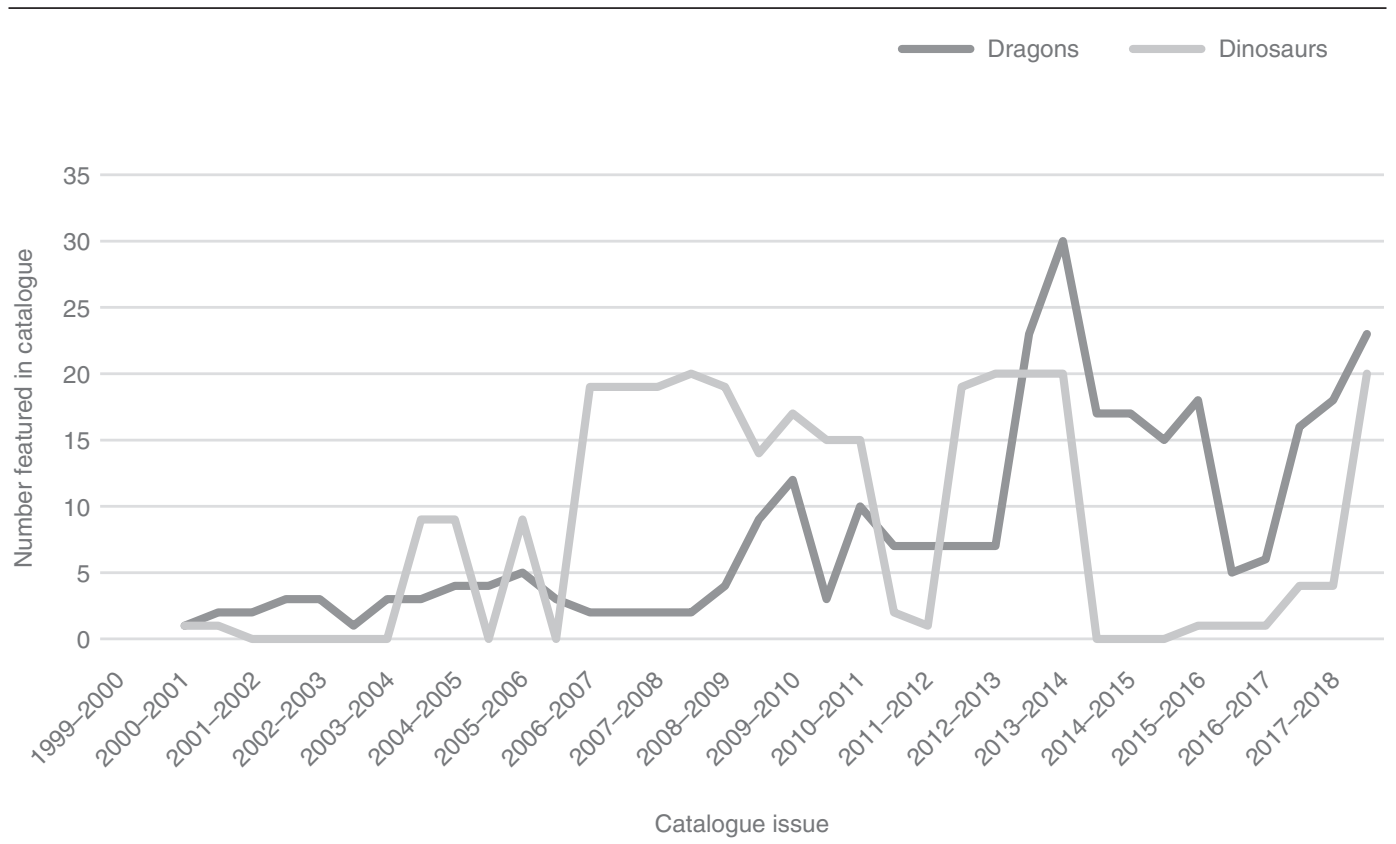

Figure 4: Business cycle of dinosaurs $(n=299)$ and dragons $(n=297)$ in Playmobil catalogues 
Playmobil's products aimed at the German and Austrian markets provide a good basis for tracing the inclusion and evolution of dragons in historical play themes. We observe almost identical numbers of dinosaurs and dragons, although dragons represent the more stable variable if we consider the distribution per year within the range, and the number of dinosaurs is subject to greater fluctuations. It is evident here that dragons are mainly associated with medieval knights and Vikings. Dinosaurs likewise appear with human figures, largely forming part of play themes in the style of the Jurassic series of films (especially after 2007), or in polar excavation activities (between 2004 and 2006). In rare instances, a dinosaur appears as a toy figure belonging to a Playmobil child. There is a notable connection with wider popular historical culture in evidence; in view of the release dates of the Jurassic films (1993, 1997, 2001, 2015, 2018 and 2021) and the DreamWorks Dragons series (films in 2010, 2014 and 2019; television series 2012-18), we can see connections that point to a rise in the production of dragons/ dinosaurs, or a maintenance or increase of the share of dinosaurs or dragons appearing in the catalogues. The figures for 2018 match perfectly with the indication of a boom in dragons that our ethnographic research in children's bedrooms has identified.

\section{Playing with dragons}

Even if we leave aside dinosaurs as real, albeit extinct, animals, the highly visible link that play worlds appear to forge between dragons and the Nordic or European Middle Ages remains striking. These dragons do not confront us as intangible intellectual or imaginative constructs, but materialise in toy figures and images that relate to modern narratives from popular culture (television, cinema, children's/young adult literature, fantasy and so on) (Medick, 2002; Änggård, 2005; Bonacker, 2012; Urbach and Eckhof, 2012). Their temporal location in these constructs, in the Nordic or European Middle Ages, means that they inevitably exercise direct or indirect influence on children's ideas about this era, even where these children take conscious care to separate fact from fiction. The semantic content of these toy dragons, ranging from wildness, brutality or alterity (rarely wisdom), to kindliness, always extends to this historical era. It is clearly the case that, within reductive, ideal-typical representations of the past, and a certain one-sided imaginative response (as frequently observed in media transmitting conceptions of popular history), Vikings and knights appear particularly apt receptacles for cultural and historical treasuries of ideas around dragons and their worlds, without causing present-day users the confusion that they might feel were they attempting to apply a strictly correct historical lens. As we know from other areas of historical culture, a representation of the past must be consistent with its target audience's level of knowledge and ideas about that past, and evidence-based findings and historically sound approaches are of secondary importance (Zimmerman, 2008: 144).

We have little empirical research on the stories that children act out using such figures. If, however, our interest lies in playability in a supposed or actual past, we can draw on similar research around play with toy castles and their residents (see Kühberger and Karl, 2021) to identify three plausible theoretical models of the emergence of play: (1) set narratives; (2) the social affordance of the objects played with; and (3) drives explainable by depth psychology.

\section{Set narratives}

When playing with toy dragons, it helps if the player knows a narrative that can be retold, modified or extended, or perhaps even consciously ignored. Such stories are either already a part of the cultural repository in which the child is immersed (a Central 
European example might be the story of St George) (Röhrich, 2000: 188-9), or require the child to transfer them from other narrative representations (children's books, films, television series and so on) to the toy. As the examples above show, and this need for narrative might reveal as unsurprising, the dragons that feature in currently popular toy sets are increasingly losing their fearsomeness and malignity, and are undergoing re-narration as tame, kindly beasts who serve as somewhat 'oddball' friends to children in need. As clear outsiders, quirky eccentrics or creatures threatened with extinction, they are no longer simply antagonists to the heroes of the stories without any special character or feelings of their own, but possess sympathetic qualities under their scales (Bonacker, 2012), and may indeed be a child protagonist's partner in overcoming evil.

Without doubt, the advertising issued by the toy industry is likewise an inestimable source of inspiration for the construction of narratives for dragon play. Targeted directly at children, it may provide suggestions for stories to re-enact in play. The Playmobil catalogues do not simply position their products in neutral settings, but stage colourful scenes involving narrative structures. A picture on pages 24-5 of a 2014/15 Playmobil catalogue for Germany shows a supposed scene from the Asian Middle Ages, featuring knights and dragons fighting together on the same side against opponents likewise composed of knights and dragons. The child's imagination can take care of the rest. We might interpret this scene - with its dynamics and the skilfully created photographic montage, including shadows, illuminated outlines of dragons, and other similar elements - as distinctly engaging for children, drawing them into play. That said, it is important to note that children who are not familiar with such narratives, and who may not have access to the packaging of the toy, with the scenes it inspires, will switch to other well-known narratives, such as playing 'families', and ignore the new context of the character-focused play world.

\section{Social affordance}

Affordance theory seeks to explain the use of a thing (in this case, a toy) on the basis of the action-related properties inscribed into its design. This theory would read play as emerging through the child's active engagement with the toy and the possibilities inherent to it. In taking up a dragon figure to play with, children connect, in play and in narrative action, with the predefined thematic complex surrounding the object they use for this purpose. The affordance for play built into the toy dragon determines its possible uses; it may fly by virtue of its wings, and its claws and fire can serve as weapons. It is evident that such dragons also possess culturally inscribed attributes, which, however, only reveal themselves to children during their use as objects, and thus enter as cultural objects into children's conceptions of the world (Gibson, 1977; Fox et al., 2015).

\section{Psychological drives}

Alternatively, we could conceive of a toy dragon as an object with which children manage to distance themselves from their own experience. From a psychotherapeutic perspective, such games with toy figures represent a limitation of consciousness which frequently brings forth elements of the unconscious with striking immediacy (Von Staabs, 1978: 12-13). Dragons, knights and pirates feature among the figures that therapeutic Playmobil sets use to explore aspects of depth psychology in therapy situations. There is no generally valid catalogue of what children's actions mean psychologically; this reveals itself through play, the figures children choose, and the functions they assign to them. This therapeutic use of play figures points to 
the psychological significance inherent, and sometimes dominant, in children's play, both within and outside therapeutic settings. On occasion, the specific psychological expression in question may be the actual reason for the game, relegating the figures in their thematic set-up to the status of props which help the child to cope with past experiences or present life, to try out alternative courses of action, or to understand situations (Lehmhaus and Reiffen-Züger, 2018: 168-80). In the final analysis, the history educator Markus Bernhardt (2016: n.p.) argues in a similar vein when he notes, in relation to Game of Thrones:

This fictitious world is based on the imagined emotional state of today's world that is characterised by an ever increasing fear of the future, nurtured by real or imagined threats and dangers. And this is how 'Game of Thrones' has become a parable for future fears that live off imaginative interpretations of the past and experience of the present.

\section{The implications for history education}

From a history education perspective, the question arises as to how these fantastical play worlds might influence the historical thinking that we intend our young people to acquire in school. There is doubtless a challenge here to the development of historical thinking, the purpose of which is to differentiate between fact and fiction in the service of initiating and developing historical consciousness in students. We need, of course, to be aware of children's life-worlds, and of the extensive diversity in the worlds of their thought that the qualitative insights presented here reveal. Viewed historically, it would appear highly problematic for historical learning, for example, to retain and explore only the present-day understanding that dragons did not exist; dismissing dragons as nothing but a pre-palaeontological misinterpretation is as inadequate in this regard as is pointing exclusively to their fictional character, in banishing them from the sphere of engagement with the factual past. Dragons were regarded as real for long periods of European cultural history. Accordingly, we need to take past mentalities seriously as explanations for phenomena, and we need to present alterity of thinking in times gone by as a manner of access to understanding that past. If history classes devote themselves to the dinosaurs and dragons which already populate pupils' rooms at home, profound insights may emerge into the development of our cultures and our understanding of science today. This approach may open a path to engagement with myth and science in their opposition to one another (Buckland, 1999; Debus, 2016; Schluchter, 2019).

The overlaps between fantasy and history manifested in films and toys should also be examined as a cultural expression of our day. The focus here should be on identifying the functions of such narratives and of their interplay with myth, which evidently exerts an appealing force time and again in the course of history. This could additionally provide a route of access to the modes of play outlined above, drawing in the use of familiar narratives, social affordance and the psychological processing of experiences and feelings. Other toys which attempt to make a more factual and less fictional/ fantastical approach to the past likewise serve as sites of these modes, which relegate the discovery or interpretation of that more factual past to a secondary place among the various purposes of play. In interacting with the toys we found in their rooms, our child participants presumably acquire iconographic, formal and narrative landmarks that later serve to anchor their systematic processes of historical learning, enabling them to rearrange, discard or build on conceptual ideas that had been chaotic, or rudimentary, when they first emerged in play. The key point is the fact that distinction between fantasy 
and reality does not take place automatically, but requires explicit instruction for its evocation. If we do not wish our children to remain under the unquestioned influence of fictional moments from historical popular culture, we need to bring the depictions of the past that populate their play worlds into the history classroom, where we can help them distinguish fact from fiction - at least as far as each pertains to history. Doing this would permit us to incorporate toys and games with references to the past into the repertoire of approaches to the formal teaching of history that enable children to explore the liminal space between history and fiction, and to draw the appropriate boundaries (see Solé et al., 2016; Cooper and Ditchburn, 2009; Curthoys, 2011).

\section{Acknowledgements}

I would like to express my gratitude to my students, who helped me collect the ethnographic data and discussed the cases with me: Michaela Baur, Walter Brandstätter, Fabian Groiß, Lena Leßlhuber, Raphael Rettenbacher, Marco Freitag, Julia Petutschnig and Beatrice Wieser. Our special thanks are, of course, due to the children who were willing to take part in this research, and to their families for their support.

\section{Research ethics statement}

The author declares that research ethics approval for this research design was provided by the Ethics Committee of the University of Salzburg.

\section{Consent for publication statement}

The author declares that research participants' informed consent to publication of findings - including photos, videos and any personal or identifiable information - was secured prior to publication.

\section{Conflicts of interest statement}

The author declares no conflict of interest with this work.

\section{Notes on the contributor}

Christoph Kühberger is Professor of History Education and Civic Education, and Head of the Department of History, at the University of Salzburg, Austria. He has previously held positions as Professor of European Cultural History at the University of Hildesheim (Germany), and Professor of History Education and Civic Education at the Salzburg University of Education Stefan Zweig (Austria). His current research interests include history education and civic education, ethnography, historical culture, new cultural history, and the ethics of history as an academic discipline.

\section{References}

Alderson, P. and Morrow, V. (2011) The Ethics of Research with Children and Young People: A practical handbook. London: Sage.

Änggård, E. (2005) 'Barbie princesses and dinosaur dragons: Narration as a way of doing gender'. Gender and Education, 17 (5), 539-53. https://doi.org/10.1080/09540250500192777.

Bernhardt, M. (2016) 'Game of Thrones and Leviathan'. Public History Weekly, 23 (4). https://doi.org/10.1515/phw-2016-6485. 
Bonacker, M. (2012) 'Domestizierte Drachen: Von der Zähmung und Auswilderung kinderliterarischer Drachen'. In F. Chen and T. Honegger (eds), Good Dragons Are Rare: An inquiry into literary dragons East and West. Frankfurt: Peter Lang, 191-214.

Buckland, W. (1999) 'Between science fact and science fiction: Spielberg's digital dinosaurs, possible worlds, and the new aesthetic realism'. Screen, 40 (2), 177-92. https://doi.org/10.1093/ screen/40.2.177.

Christians, C. (2000) 'Ethics and politics in qualitative research'. In N.K. Denzin and Y.S. Lincoln (eds), The SAGE Handbook of Qualitative Research. 2nd ed. London: Sage, 125-67.

Cooper, H. and Ditchburn, E. (2009) 'Folk tales: Universal values, individual differences'. International Journal of Historical Learning, Teaching and Research, 8 (1), 58-71. Accessed 29 July 2021. www.history.org.uk/secondary/resource/2033/the-internationaljournal-volume-8-number-1.

Curthoys, A. (2011) 'Harry Potter and historical consciousness: Reflection on history and fiction'. History Australia, 8 (1), 7-22. https://doi.org/10.1080/14490854.2011.11668354.

Curthoys, A. (2014) 'The magic of history: Harry Potter and historical consciousness'. Agora, 49 (4), 23-31.

Debus, A.A. (2016) Dinosaurs Ever Evolving: The changing faces of prehistoric animals in popular culture. Jefferson: McFarland.

De Groot, J. (2016) Remaking History: The past in contemporary historical fictions. London: Routledge.

Eissle, N. (2009) 'Kleiner Hobbit - großer Artus: Populäre mittelalterliche Mythen und ihr Potential für die Förderung historischen Denkens'. In B. Korte and S. Paletschek (eds), History Goes Pop: Zur Repräsentation von Geschichte in populären Medien und Genres. Bielefeld: transcript, 83-102.

Fox, R., Panagiotopoulos, D. and Tsouparopoulou, C. (2015) 'Affordanz/Affordance'. In T. Meier, M. Ott. and R. Sauer (eds), Materiale Textkulturen: Konzepte - Materialien - Praktiken. Berlin: De Gruyter, 63-70.

Fraiberg, S. (1998) Die magischen Jahre: Familiäre Beziehungen in der frühen Kindheit. Reinbek: Rowohlt.

Gibson, J. (1977) 'The theory of affordance'. In R. Shaw and J. Bransford (eds), Perceiving, Acting, and Knowing: Toward an ecological psychology. Hillsdale, NJ: John Wiley \& Sons, 67-82.

Groiß, J.T. (2002) 'Paläontologische Anmerkungen zu den "Drachen"'. In A. Grafetstätter and N. Krines (eds), Mythos Drache - Schwingen, Schuppen, Schwefeldampf: Katalog zur Ausstellung. Bamberg: Historisches Museum Bamberg, 54-8.

Hinz, F. and Körber, A. (2020) Geschichtskultur - Public History - Angewandte Geschichte. Göttingen: Vandenhoeck-Ruprecht.

Kicks, A. and Martin, D. (1997) 'Teaching English and history through historical fiction'. Children's Literature in Education, 28 (2), 49-59. https://doi.org/10.1023/A:1025067728986.

Kühberger, C. (2019) 'Toys with historical references as part of a material culture: An ethnographic study on children's bedrooms'. 8th International Toy Research Association World Conference, International Toy Research Association (ITRA), July 2018, Paris. Accessed 14 July 2021. https://hal.archives-ouvertes.fr/hal-02090966/.

Kühberger, C. (2020) 'Spielzeug'. In F. Hinz and A. Körber (eds), Geschichtskultur - Public History Angewandte Geschichte. Göttingen: Vandenhoeck-Ruprecht, 282-303.

Kühberger, C. and Karl, K. (2021) 'Die Ritterburg im Kindergarten: Ethnographische Annäherungen an den Umgang mit einem geschichtskulturellen Produkt'. In C. Kühberger (ed.), Ethnographie und Geschichtsdidaktik. Frankfurt: Wochenschau, 180-211.

Küppers, W. (1961) Zur Psychologie des Geschichtsunterrichtes. Bern: Huber/Klett.

Lehmhaus, D. and Reiffen-Züger, B. (2018) Spiel und Spielen in der psychodynamischen Kinder- und Jugendpsychotherapie. Stuttgart: Kohlhammer.

Lincoln, S. (2012) Youth Culture and Private Space. New York: Palgrave.

Medick, M. (2002) 'Der Drache im Spielfilm: Die Entwicklungsgeschichte einer kollektiven Bewältigung'. In A. Grafetstätter and N. Krines (eds), Mythos Drache - Schwingen, Schuppen, Schwefeldampf: Katalog zur Ausstellung. Bamberg: Historisches Museum Bamberg, 74-6.

Morison, P. and Gardner, H. (1978) 'Dragons and dinosaurs: The child's capacity to differentiate fantasy from reality'. Child Development, 49 (3), 642-8. https://doi.org/10.2307/1128231.

Oswald, V. and Pandel, H.-J. (eds) (2021) Geschichtskultur im Unterricht. Frankfurt: Wochenschau.

Petzold, D. (2012) 'Drachen zum Lachen: Der Wandel des Drachenbildes in der spätviktorianischen Literatur'. In F. Chen and T. Honegger (eds), Good Dragons Are Rare: An inquiry into literary dragons East and West. Frankfurt: Peter Land, 171-90. 
Rebschloe, T. (2014) Der Drache in der mittelalterlichen Literatur Europas. Heidelberg: Universitätsverlag Winter.

Röhrich, L. (2000) 'Drachen - gestern und heute: Vom Wandel eines Feindbildes'. Österreichische Zeitschrift für Volkskunde, 103, 183-94. Accessed 29 July 2021. www.volkskundemuseum.at/jart/ prj3/volkskundemuseum/data/publikation/1524345942989/1524345942989.pdf.

Roth, H. (1955) Kind und Geschichte: Psychologische Voraussetzungen des Geschichtsunterrichtes in der Volksschule. Munich: Kösel.

Rüsen, J. (2013) Historik. Vienna: Böhlau.

Samuels, A. and Taylor, M. (1994) 'Children's ability to distinguish fantasy events from real-life events'. British Journal of Developmental Psychology, 12 (4), 417-27. https://doi.org/10.1111/ j.2044-835X.1994.tb00644.x.

Schluchter, J.-R. (2019) 'Dinosaurier im Film - Pädagogische Relevanz(en)'. Ludwigsburger Beiträge zur Medienpädagogik, 20, 1-21. https://doi.org/10.21240/lbzm/20/11.

Schneidewind, F. (2012) 'Von Babylon bis Eragon: Die Wechselwirkung von Mythos/ Literatur und (Natur)Wissenschaft in der westlichen Drachendarstellung'. In F. Chen and T. Honegger (eds), Good Dragons Are Rare: An inquiry into literary dragons East and West. Frankfurt: Peter Land, 1-26.

Solé, G., Reis, D. and Machado, A. (2016) 'The potentialities of using historical fiction and legends in history teaching: A study with Portuguese primary education students'. International Journal of Historical Learning, Teaching and Research, 14 (1), 137-54. Accessed 14 July 2021. www.history. org.uk/publications/resource/9035/the-international-journal-volume-14-number-1.

Sullivan, R.M. (2006) 'A taxonomic review of the Pachycephalosauridae (Dinosauria: Ornithischia)'. In L.G. Spencer and R.M. Sullivan (eds), Late Cretaceous Vertebrates from the Western Interior (New Mexico Museum of Natural History and Science Bulletin, 35). Albuquerque, NM: New Mexico Museum of Natural History and Science, 347-65.

Urbach, J. and Eckhof, A. (2012) 'Release the dragon: The role of popular culture in children's stories'. Contemporary Issues in Early Childhood, 13 (1), 27-37. http://doi.org/10.2304/ ciec.2012.13.1.27

Von Staabs, G. (1978) Der Scenotest: Beitrag zur Erfassung unbewusster Problematik und charakterologischer Struktur in Diagnostik und Therapie. Bern: Huber.

Zimmermann, M. (2008) 'Der Historiker am Set'. In T. Fischer and R. Wirtz (eds), Alles authentisch? Popularisierung der Geschichte im Fernsehen. Konstanz: UVK, 137-60. 